\title{
HUBUNGAN KEMAMPUAN KETERAMPILAN DASAR MENGAJAR MAHASISWA PROGRAM PENGALAMAN LAPANGAN (PPL) JURUSAN TEKNIK SIPIL FAKULTAS TEKNIK UNIVERSITAS NEGERI JAKARTA TERHADAP HASIL BELAJAR SISWA DI SMK PADA BIDANG KEAHLIAN TEKNIK BANGUNAN GEDUNG
}

\author{
Yudhi Tri Pratama, Tuti Iriani, Amos Neolaka
}

\begin{abstract}
This research aims to determine the relationship between student's basic skill of teaching during Teaching Apprenticeship Program $(P P L)$ at the Department of Civil Engineering Faculty of Engineering - State University of Jakarta and the results of learning process at vocational school majoring in building engineering.

The research was conducted in nine vocational schools majoring in building engineering in the second semester - school year 2011/2012. The method used is surveying with the correlation approach, student's basic skill of teaching data obtained from 240 samples PPL using Likert questionnaire that had been tested its model of validity and reliability. Validation is done by analyzing each item of proble; while reliability is obtained by using a formula that produces alpha $r$ of 0.971 with the interpretation criteria is very high.

Preparation of hypothesis testing is using regression done by generating a regression equation $Y=37.493+0.238 x$. Hypothesis testing is done by $t$ test and obtained $t_{\text {count }}>T_{\text {table }}$ with $\alpha=0.05$ (8.65> 1.651). Further, testing of correlation coefficient $\left(r_{x y}\right)$ with Product Moment formula obtained $r_{x y}=0.489$, the value shows the pattern of relationships was quite variable. The result of calculation of the coefficient of determination $\left(r_{x y}{ }^{2}\right)$ is 0.239 . This means that the students' vocational $23.90 \%$ influenced by teaching students the basic skills of PPL. Thus the study concluded there is a relationship between teaching students the basic skills of the Field Experience Program (PPL) Department of Civil Engineering Faculty of Engineering, State University of Jakarta on vocational students' basic skills in the areas of teaching expertise.
\end{abstract}

Keywords: basic skill of teaching, learning process

\begin{tabular}{|l|r|r|}
\hline Yudhi Tri Pratama & Dr. Tuti Iriani, M.Si & Prof. Dr. Amos Neolaka \\
Alumni Jurusan Teknik Sipil & Jurusan Teknik Sipil & Jurusan Teknik Sipil \\
Fakultas Teknik & Fakultas Teknik & Fakultas Teknik \\
Universitas Negeri Jakarta, 13220 & $\begin{array}{c}\text { Universitas Negeri Jakarta, 13220 } \\
\text { email :t_iriani@yahoo.com }\end{array}$ & $\begin{array}{l}\text { Universitas Negeri Jakarta, 13220 } \\
\text { email:amos_neolaka@yahoo.com }\end{array}$ \\
\hline
\end{tabular}

PENDAHULUAN 
UNJ sebagai salah satu LPTK (Lembaga Pendidik Tenaga Kependidikan) memiliki komitmen yang kuat untuk senantiasa menghasilkan lulusan/tenaga akademik (pendidik) yang bermutu dan professional. Untuk mencapai tujuan tersebut diperlukan suatu program yang memberikan pengayaan dan pengembangan diri kependidikan berupa latihan profesional bagi mahasiswa calon pendidik. Dalam lingkup UNJ, latihan profesional tersebut dinamakan Program Pengalaman Lapangan (PPL) (UNJ, 2009:1).

Dalam buku Pedoman Program Pengalaman Lapangan (PPL) (2009:1), PPL adalah suatu program yang merupakan ajang pelatihan untuk menerapkan berbagai pengetahuan, sikap dan ketrampilan dalam rangka pembentukan calon guru dan tenaga kependidikan yang profesional. Sedangkan tujuan umum PPL adalah untuk melatih mahasiswa agar memiliki kemampuan untuk menerapkan berbagai pengetahuan, sikap dan keterampilan yang dipelajari dalam situasi nyata, baik untuk kegiatan mengajar maupun tugas-tugas non mengajar dalam rangka membentuk calon guru dan tenaga kependidikan professional.

Di dalam pelaksanaan PPL, mahasiswa PPL akan didampingi oleh guru pamong dan dosen pembimbing. Guru pamong merupakan guru yang bertugas mendampingi mahasiswa selama PPL di sekolah latihan dan merupakan guru kelas terkait dengan bidang studi yang ditekuni oleh mahasiswa. Dosen pembimbing berperan membimbing dan mengarahkan mahasiswa dalam pelaksanaan PPL, melaksanakan supervisi lapangan, membimbing mahasiswa dalam penyusunan perangkat pembelajaran, membimbing mahasiswa dalam penyusunan laporan PPL, menguji mahasiswa dalam pelaksanaan praktik mengajar, dan melakukan evaluasi terhadap kegiatan mahasiswa selama praktik di sekolah latihan. Sebelum melakukan praktik mengajar di sekolah, mahasiswa PPL harus melalui pelatihan belajar mengajar. Kegiatan latihan atau microteaching tersebut dilakukan saat mahasiswa menempuh mata kuliah Kompetensi Pengajaran.

PPL wajib diikuti oleh setiap mahasiswa UNJ yang mengambil program kependidikan. PPL dilaksanakan di sekolah mitra yang ditunjuk oleh UNJ serta memiliki persyaratan tertentu. Keterampilan dasar mengajar guru PPL didasarkan oleh apa yang ia dapat selama proses belajar di UNJ. Baik itu dari Matakuliah Pengembangan Kepribadian (MPK), Matakuliah Keilmuan dan Keterampilan (MKK), Matakuliah Keahlian Berkarya (MKB), Matakuliah Perilaku Berkarya (MPB) dan Matakuliah Berkehidupan Bermasyarakat (MBB) (Suyanti, 2009:1). Akan tetapi tidak semua guru PPL memiliki keterampilan dasar mengajar yang sama. Ini dikarenakan oleh beberapa hal, diantaranya: bakat keterampilan dasar mengajar setiap guru PPL, perbedaan tingkat kesiapan guru PPL dalam menghadapi proses kegiatan belajar mengajar itu sendiri, kepercayaan diri, kesadaran dan tanggung jawab sebagai seorang guru PPL.

Keterampilan dasar dalam mengajar merupakan salah satu keterampilan yang menuntut latihan yang terprogram untuk dapat menguasainya. Penguasaan terhadap keterampilan ini memungkinkan

Perbedaan Pembelajaran Menggunakan Aplikasi Multimedia Presentasi dengan Pembelajaran Media Program Pengolah Kata terhadap Hasil Belajar Mata Pelajaran Teori Kejuruan Teknik Furnitur (Studi pada Mata Pelajaran Kejuruan Furnitur Kelas XI SMKN 52 Jakarta) Hadi Mukhlish, T uti Iriani, R. Eka Murtinugraha 
seorang mahasiswa PPL mampu mengelola kegiatan pembelajaran secara efektif. Dengan penguasaan keterampilan dasar mengajar, mahasiswa diharapkan mampu meningkatkan kualitas proses pembelajaran. Keterampilan dasar mengajar, merupakan faktor yang sangat signifikan dalam menunjang proses pembelajaran maupun interaksi guru dan siswa di dalam kelas agar pencapaian mutu pendidikan dapat terwujud.

Penguasaan keterampilan dasar mengajar ini sangat perlu dikuasai oleh mahasiswa UNJ sebagai calon guru. Secara umum keterampilan dasar dalam mengajar terdiri atas: keterampilan bertanya, keterampilan memberi penguatan, keterampilan memberi variasi, keterampilan membuka dan menutup pelajaran, keterampilan mengelola kelas, keterampilan membimbing diskusi kelompok kecil dan keterampilan menjelaskan. Dengan demikian keterampilan dasar mengajar tersebut harus senantiasa dikembangkan oleh guru untuk mencapai tujuan pengajaran. Keterampilan dasar mengajar sangat penting dikuasai oleh mahasiswa PPL sebagai calon guru, karena betapapun tingginya ilmu yang dimiliki oleh seorang guru itu, jika tidak menguasai keterampilan dasar mengajar, maka akan sulit bagi seorang siswa menyerap ilmu yang diberikan oleh guru tersebut. Jika guru memiliki keterampilan dasar mengajar yang baik, maka hasil belajar pun akan baik. Begitu pula jika guru memiliki keterampilan dasar mengajar yang kurang, maka hasil belajar pun akan kurang.

Prestasi belajar merupakan tolak ukur yang utama untuk mengetahui keberhasilan belajar seseorang. Seorang yang prestasinya tinggi dapat dikatakan bahwa ia telah berhasil dalam belajar. Prestasi belajar adalah tingkat pengetahuan sejauh mana penguasaan anak terhadap materi yang diterima (Slameto, 2003:17). Prestasi belajar siswa adalah hasil belajar yang dicapai siswa ketika mengikuti dan mengerjakan tugas dan kegiatan pembelajaran di sekolah (Tu'u, 2004:75). Salah satu yang berperan dalam menentukan hasil belajar siswa adalah keterampilan dasar mengajar mahasiswa PPL.

Menjadi seorang guru bukanlah hal yang mudah. Pengalaman pertama dalam mengajar serta pengetahuan yang masih dasar merupakan hambatan dalam mengajar di kelas. Menurut James B. Brow seperti yang dikutip oleh Sardiman (2011), mengemukakan bahwa tugas dan peranan guru antara lain: menguasai dan mengembangkan materi pelajaran, merencana dan mempersiapkan pelajaran sehari-hari, mengontrol dan mengevaluasi kegiatan siswa. Untuk menjadi seorang guru profesional mahasiswa PPL harus menguasai 8 komponen keterampilan dasar mengajar. Hal inilah yang menjadi pokok permasalahan yang akan dibuktikan dalam penelitian ini mengenai keterampilan mengajar mahasiswa PPL Jurusan Teknik Sipil UNJ.

Dari uraian di atas, maka penulis tertarik untuk melakukan penelitian dengan judul: "Hubungan Kemampuan Keterampilan Dasar Mengajar Mahasiswa Program Pengalaman Lapangan (PPL) Jurusan Teknik Sipil Fakultas Teknik Universitas Negeri Jakarta dengan Hasil Belajar Siswa di SMK pada Bidang Keahlian Teknik Bangunan Gedung." 


\section{Hakikat Ketrampilan Dasar Mengajar}

Ketrampilan adalah kemampuan atau kompetensi yang dimiliki seseorang. Ketrampilan secara etimologi (Kamus Besar Bahasa Indonesia 2002) adalah kecakapan untuk menyelesaikan tugas. Sedangkan menurut Syah (2002:119) keterampilan adalah kemampuan melakukan pola-pola tingkah laku yang kompleks dan tersusun rapi secara mulus serta sesuai dengan keadaan untuk mencapai hasil tertentu. Keterampilan bukan hanya meliputi gerakan motorik melainkan juga fungsi mental yang bersifat kognitif. Jadi keterampilan merupakan usaha untuk memperoleh kompetensi cekat, cepat dan tepat dalam menghadapi permasalahan belajar untuk mengembangkan sifat kognitif, afektif dan psikomotor.

Pengertian mengajar menurut Basyirudin (2002:15) ialah menanamkan pengetahuan atau menyampaikan bahan pelajaran kepada seseorang sehingga dapat dikuasai atau dimiliki siswa yang menerimanya. Menurut Sardiman (2011:55) mengajar merupakan kegiatan yang tidak bias dilepaskan dari belajar. Mengajar adalah usaha untuk menjadikan kondisi yang kondusif agar berlangsung kegiatan belajar yang bermakana optimal. Jadi mengajar adalah suatu rangkaian kegiatan penyampaian pelajaran kepada siswa agar dapat menerima, menanggapi, menguasai dan mengembangkan bahan pelajaran tersebut.

Menurut Glicman, diacu dalam Sukirman (2011:3) keterampilan dasar mengajar (teaching skills) adalah kemampuan atau keterampilan yang bersifat khusus (most specific instructional behaviours) yang harus dimiliki oleh guru, dosen, instruktur, atau widyaiswara agar dapat melaksanakan tugas mengajar secara efektif, efisien, dan professional. Sedangkan menurut Sukirman (2011:3) keterampilan dasar mengajar berkenaan dengan beberapa kemampuan atau keterampilan yang bersifat mendasar dan melekat harus dimiliki dan diaktualisasikan oleh setiap guru, dosen, instruktur, atau widyaiswara dalam melaksanakan tugas mengajarnya.

Berdasarkan pendapat-pendapat tersebut, dapat diketahui bahwa keterampilan dasar mengajar guru merupakan kemampuan atau keahlian dasar seorang guru dalam melaksanakan dan mengelola kegiatan mengajar agar tercipta kualitas proses pembelajaran yang baik. Keterampilan dasar mengajar harus dimiliki dan dikuasai oleh setiap guru sebagai kemampuan dasar untuk melaksanakan proses pembelajaran. Keterampilan dasar mengajar diperlukan oleh guru untuk menciptakan proses pembelajaran yang efektif dan efisien.

\section{Jenis-Jenis Keterampilan Dasar Mengajar}

Ada beberapa jenis keterampilan dasar mengajar yang dikemukakan oleh beberapa ahli. Winkel (1986), diacu dalam Uno (2010: 170) mengemukakan bahwa keterampilan dasar mengajar terbagi menjadi 4 yaitu :

1 Keterampilan memberikan penguatan

2 Keterampilan menjelaskan

Perbedaan Pembelajaran Menggunakan Aplikasi Multimedia Presentasi dengan Pembelajaran Media Program Pengolah Kata terhadap Hasil Belajar Mata Pelajaran Teori Kejuruan Teknik Furnitur (Studi pada Mata Pelajaran Kejuruan Furnitur Kelas XI SMKN 52 Jakarta) Hadi Mukhlish, T uti Iriani, R. Eka Murtinugraha 
3 Keterampilan bertanya

4 Keterampilan dalam membuka dan menutup pelajaran.

Pendapat lain dikemukakan oleh Sardiman (2011:221) bahwa keterampilan dasar mengajar terbagi menjadi tujuh, yaitu :

1 Keterampilan membuka pelajaran

2 Mendorong dan melibatkan siswa

3 Mengajukan pertanyaan

4 Menggunakan isyarat nonverbal

5 Menanggapi siswa

6 Menggunakan waktu (membuka pelajaran, menggarap/membahas bahan dan menutup pelajaran), serta

7 Mengakhiri pelajaran.

Sedangkan menurut Usman (2009:74-108) ada delapan keterampilan dasar yang mutlak harus dimiliki seorang guru untuk menjadi tenaga pendidik yang baik, yaitu:

1 Keterampilan bertanya

2 Keterampilan memberi penguatan

3 Keterampilan mengadakan variasi

4 Keterampilan menjelaskan

5 Keterampilan membuka dan menutup pelajaran

6 Keterampilan membimbing diskusi kelompok kecil

7 Keterampilan mengelola kelas

8 Keterampilan mengajar kelompok kecil dan perseorangan

Penjelasan dari keterampilan mengajar tersebut adalah sebagai berikut :

1 Bertanya merupakan ucapan atau pertanyaan yang dilontarkan guru yang menuntun respon atau jawaban dari siswa, bertujuan untuk memotivasi siswa agar terlibat dalam interaksi belajar.

2 Penguatan merupakan segala bentuk respons, baik bersifat verbal maupun non verbal yang merupakan modifikasi dari tingkah laku guru atas tingkah laku siswa bertujuan memberi umpan balik kepada siswa atas perbuatannya, baik sebagai pendorong ataupun koreksi.

3 Mengadakan variasi merupakan suatu kegiatan guru dalam konteks proses interaksi belajar mengajar yang ditujukan untuk mengatasi kebosanan siswa, sehingga dalam proses belajarnya siswa menunjukkan ketekunan, keantusiasan serta berperan aktif.

4 Menjelaskan adalah pemberian penjelasan yang merupakan salah satu aspek yang sangat penting dari kegiatan guru dalam interaksinya dengan siswa di dalam kelas.

5 Membuka pelajaran bertujuan untuk menciptakan prakondisi bagi siswa agar mental maupun perhatian terpusat pada apa yang akan dipelajari. Menutup pelajaran bertujuan untuk memberi 
gambaran secara menyeluruh tentang apa yang telah dipelajari oleh siswa, mengetahui tingkat pencapaian siswa dan keberhasilan guru dalam proses pembelajaran.

6 Diskusi kelompok kecil adalah suatu proses yang teratur dengan melibatkan sekelompok siswa dalam interaksi tatap muka yang optimal dengan tujuan berbagi pengalaman, pengambilan kesimpulan atau pemecahan masalah.

7 Keterampilan mengelola kelas merupakan keterampilan guru untuk menciptakan dan memelihara kondisi belajar yang optimal dan mengembalikannya ke kondisi yang optimal bila terjadi gangguan dalam proses pembelajaran.

8 Keterampilan mengajar kelompok kecil atau perorangan adalah jika siswa yang dihadapi oleh guru berjumlah terbatas, yaitu berkisar 3-8 orang untuk kelompok kecil dan seorang untuk perorangan. Pada dasarnya bentuk pengajaran ini dapat dikerjakan dengan membagi kelas dalam kelompok-kelompok yang lebih kecil.

Jadi dalam proses belajar mengajar, penguasaan delapan ketrampilan dasar mengajar ini diharapkan akan membantu siswa dalam memahami materi ajar dengan baik. Jika dalam pelaksanaannya kurang baik, maka dikhawatirkan akan timbul pemahaman yang kurang baik sehingga siswa tidak dapat mencapai hasil belajar yang optimal.

\section{Hakikat Hasil Belajar}

Hasil belajar adalah hasil yang dicapai oleh siswa yang telah mengikuti proses belajar mengajar. Hasil pada dasarnya merupakan sesuatu yang diperoleh dari suatu aktivitas, sedangkan belajar merupakan suatu proses yang mengakibatkan perubahan pada individu, yakni perubahan tingkah laku, baik aspek pengetahuannya, keterampilannya, maupun aspek sikapnya. Hasil belajar merupakan istilah yang digunakan untuk menunjukkan tingkat keberhasilan yang dicapai oleh seseorang setelah melakukan usaha tertentu. Dalam hal ini hasil belajar yang dicapai siswa dalam bidang studi tertentu setelah mengikuti proses belajar mengajar.

Sardiman (2011:19) mengemukakan bahwa dari proses belajar-mengajar ini akan diperoleh suatu hasil, yang pada umumnya disebut hasil pengajaran, atau dengan istilah tujuan pembelajaran atau hasil belajar. Menurut Hamalik (2006:30) hasil belajar adalah bila seseorang telah belajar akan terjadi perubahan tingkah laku pada orang tersebut, misalnya dari tidak tahu menjadi tahu, dan dari tidak mengerti menjadi mengerti Sedang menurut Dimyati \& Mudjiono (2002:4-5) hasil belajar dapat dibedakan menjadi dua yaitu dampak pengajaran dan dampak pengiring. Dampak pengajaran adalah hasil yang dapat diukur, seperti tertuang dalam angka raport, angka dalam ijazah, atau kemampuan meloncat setelah latihan. Dampak pengiring adalah terapan pengetahuan dan kemampuan dibidang lain, suatu transfer belajar.

Perbedaan Pembelajaran Menggunakan Aplikasi Multimedia Presentasi dengan Pembelajaran Media Program Pengolah Kata terhadap Hasil Belajar Mata Pelajaran Teori Kejuruan Teknik Furnitur (Studi pada Mata Pelajaran Kejuruan Furnitur Kelas XI SMKN 52 Jakarta) 
Berdasarkan teori Taksonomi Bloom hasil belajar dalam rangka studi dicapai melalui tiga kategori ranah antara lain kognitif, afektif, psikomotorik. Ranah kognitif berkenaan dengan hasil belajar intelektual yang terdiri dari 6 aspek yaitu pengetahuan, pemahaman, penerapan, analisis, sintesis dan penilaian. Ranah afektif berkenaan dengan sikap dan nilai. ranah afektif meliputi lima jenjang kemampuan yaitu menerima, menjawab atau reaksi, menilai, organisasi dan karakterisasi dengan suatu nilai atau kompleks nilai. Ranah psikomotor meliputi keterampilan motorik, manipulasi benda-benda, koordinasi neuromuscular (menghubungkan, mengamati).Tipe hasil belajar kognitif lebih banyak digunakan daripada afektif dan psikomotor karena berkaitan dengan dengan kemampuan siswa menguasai isi bahan ajar, namun hasil belajar psikomotor dan afektif juga harus menjadi bagian dari hasil penilaian dalam proses pembelajaran di sekolah.

Hasil belajar dalam pengertian yang luas dapat berupa perubahan kepribadian menjadi lebih baik, sedang hasil belajar untuk pengertian belajar yang sempit dapat terlihat dari pemahamannya mengenai materi atau ilmu pengetahuan yang telah diberikan guru di kelas. Untuk mengetahui hasil belajar siswa maka guru senantiasa mengadakan evaluasi, dan salah satunya adalah ulangan harian. Siswa yang mendapatkan nilai ulangan harian yang baik, maka dapat dikatakan siswa tersebut mendapatkan hasil belajar yang sudah baik. Dalam mengupayakan hasil belajar yang optimal, proses belajar yang dilalui pun harus terorganisir dengan baik.

Keberhasilan belajar siswa dipengaruhi oleh berbagai faktor yang saling berinteraksi baik internal maupun eksternal. Faktor internal berasal dari dalam diri siswa, diantaranya: bakat dan minat belajar, kepribadian, sikap, kebiasaan belajar, dan lain-lain, sedangkan faktor eksternal adalah faktor yang berasal dari luar, seperti lingkungan sekolah, keluarga, dan masyarakat. Ini didukung oleh pendapat Slameto (2010: 54) bahwa faktor-faktor yang mempengaruhi belajar banyak jenisnya, tetapi dapat digolongkan menjadi dua golongan saja, yaitu faktor eksternal dan faktor internal.

1. Faktor-faktor eksternal siswa

Faktor-faktor yang berasal dari luar diri siswa (eksternal) terdiri dari:

a. Faktor-faktor lingkungan, dapat dibagi menjadi dua bagian yaitu: faktor lingkungan alam/non sosial dan faktor lingkungan sosial.

b. Faktor-faktor instrumental, terdiri dari gedung/sarana fisik kelas, sarana atau alat pengajaran, media pengajaran, guru dan kurikulum/materi pelajaran serta strategi belajar mengajar yang digunakan akan mempengaruhi proes dan hasil belajar siswa.

2. Faktor-faktor yang berasal dari kondisi internal siswa terdiri dari:

a. Faktor kondisi fisisologis siswa, terdiri dari kondisi kesehatan dan kebugaran fisik dan kondisi panca inderanya terutama penglihatan dan pendengaran.

b. Faktor psikologis yang akan mempengaruhi keberhasilan belajar siswa; terdiri atas faktor minat, bakat, intelegensi, motivasi dan kemampuan kognitif seperti: kemampuan persepsi, ingatan, berfikir, dan kemampuan dasar pengetahuan yang dimiliki siswa. 
Dari uraian di atas dapat disimpulkan bahwa hasil belajar adalah suatu penilaian akhir dari proses dan pengenalan yang telah dilakukan berulang-ulang. Serta akan tersimpan dalam jangka waktu lama atau bahkan tidak akan hilang selama-lamanya karena hasil belajar turut serta dalam membentuk pribadi individu yang selalu ingin mencapai hasil yang lebih baik lagi sehingga akan merubah cara berpikir serta menghasilkan perilaku kerja yang lebih baik.

\section{METODE}

Penelitian ini menggunakan metode survei dengan pendekatan korelasional. Menurut Singarimbun (1998:46) metode survei adalah metode penelitian kuantitatif yang digunakan untuk penyelidikan informasi yang berhubungan dengan distribusi dan hubungan antar variabel dalam suatu populasi dan mengambil sampel dari satu populasi tersebut serta menggunakan kuisioner sebagai alat pengumpul data yang pokok Sedangkan pendekatan korelasional adalah pendekatan dalam penelitian yang pada pelaksanaannya menggunakan teknik analisis yang dinamakan korelasi. Teknik analisa korelasional adalah teknik analisis statistik mengenai hubungan antara dua variabel atau lebih (Anas, 2000: 35).

\section{HASIL DAN PEMBAHASAN}

Berdasarkan analisis dan hasil pengujian hipotesis yang telah dilakukan menunjukkan bahwa hipotesis yang diajukan dalam penelitian ini diterima yaitu terdapat hubungan antara keterampilan dasar mengajar mahasiswa PPL Jurusan Teknik Sipil UNJ Semester 096 dengan hasil belajar siswa SMK Semester Genap Tahun Ajaran 2011/2012.

Pola hubungan antara variabel keterampilan dasar mengajar dengan variabel hasil belajarsiswa SMK ini dinyatakan dengan persamaan regresi $\hat{Y}=37,493+0,238 x$. Persamaan ini memberikan informasi bahwa setiap perubahan baik itu peningkatan maupun penurunan satu satuan keterampilan dasar mengajar akan diikuti dengan perubahan baik peningkatan maupun penurunan pada hasil belajar siswa SMK sebesar 0,239 satuan pada konstanta 37,493.

Hasil analisis korelasi/hubungan antara keterampilan dasar mengajar dengan hasil belajarsiswa SMK diperoleh koefisien korelasi $\left(r_{\mathrm{xy}}\right)$ sebesar 0,489 . Nilai ini memberikan pengertian bahwa keterampilan dasar mengajar dengan hasil belajar memiliki hubungan yang tergolong cukup.

\section{KESIMPULAN}

Berdasarkan hasil penelitian dan pengujian, maka dapat diambil keesimpulan sebagai berikut:

1. Kemampuan mahasiswa PPL dalam indikator keterampilan bertanya sudah baik. Ini dapat terlihat dari hasil prosentase sub-sub indikator keterampilan bertanya berkategori baik. Dan sub indikator yang paling mempengaruhi kemampuan mahasiswa PPL dalam keterampilan bertanya adalah

\footnotetext{
Perbedaan Pembelajaran Menggunakan Aplikasi Multimedia Presentasi dengan Pembelajaran Media Program Pengolah Kata terhadap Hasil Belajar Mata Pelajaran Teori Kejuruan Teknik Furnitur (Studi pada Mata Pelajaran Kejuruan Furnitur Kelas XI SMKN 52 Jakarta) Hadi Mukhlish, T uti Iriani, R. Eka Murtinugraha
} 
penggunaan pertanyaan secara jelas dan singkat yang memiliki hasil prosentase paling tinggi dibandingkan dengan sub indikator lainnya. Prosentase penggunaan pertanyaan secara jelas dan singkat sebesar $81 \%$ dan masuk kategori sangat baik.

2. Kemampuan mahasiswa PPL dalam indikator keterampilan memberi penguatan cukup. Ini dapat terlihat dari hasil prosentase sub-sub indikator keterampilan bertanya berkategori cukup. Kecuali pada sub indikator penguatan gerak isyarat, penguatan pendekatan, dan penguatan dengan kegiatan yang menyenangkan yang berkategori baik. Dan sub indikator yang paling mempengaruhi kemampuan mahasiswa PPL dalam keterampilan memberi penguatan adalah penguatan dengan kegiatan yang menyenangkan yang memiliki hasil prosentase paling tinggi dibandingkan dengan sub indikator lainnya. Prosentase penguatan dengan kegiatan yang menyenangkan sebesar $76 \%$ dan masuk kategori baik.

3. Kemampuan mahasiswa PPL dalam indikator keterampilan mengadakan variasi sudah baik. Ini dapat terlihat dari hasil prosentase sub-sub indikator keterampilan bertanya berkategori baik, dan sub indikator yang paling mempengaruhi kemampuan mahasiswa PPL dalam keterampilan mengadakan variasi adalah pemusatan perhatian siswa yang memiliki hasil prosentase paling tinggi dibandingkan dengan sub indikator lainnya. Prosentase pemusatan perhatian siswa sebesar $80 \%$ dan masuk kategori sangat baik.

4. Kemampuan mahasiswa PPL dalam indikator keterampilan menjelaskan sudah baik. Ini dapat terlihat dari hasil prosentase sub-sub indikator keterampilan menjelaskan berkategori baik. Dan sub indikator yang paling mempengaruhi kemampuan mahasiswa PPL dalam keterampilan menjelaskan adalah penggunaan balikan yang memiliki hasil prosentase paling tinggi dibandingkan dengan sub indikator lainnya. Prosentase penggunaan balikan sebesar $86 \%$ dan masuk kategori sangat baik.

5. Kemampuan mahasiswa PPL dalam indikator membuka dan menutup pelajaran sudah baik. Ini dapat terlihat dari hasil prosentase sub-sub indikator membuka dan menutup pelajaran berkategori baik, dan sub indikator yang paling mempengaruhi kemampuan mahasiswa PPL dalam membuka dan menutup pelajaran adalah membuka pelajaran yang memiliki hasil prosentase lebih tinggi dibandingkan dengan sub indikator menutup pelajaran. Prosentase membuka pelajaran sebesar $76 \%$ dan menutup pelajaran sebesar $74 \%$, kedua sub indikator tersebut masuk kategori baik.

6. Kemampuan mahasiswa PPL dalam indikator membimbing diskusi kelompok kecil sudah baik. Ini dapat terlihat dari hasil prosentase sub-sub indikator membimbing diskusi kelompok kecil berkategori baik, dan sub indikator yang paling mempengaruhi kemampuan mahasiswa PPL dalam membimbing diskusi kelompok kecil adalah menyebarkan kesempatan berpartisipasi yang memiliki hasil prosentase paling tinggi dibandingkan dengan sub indikator lainnya. Prosentase menyebarkan kesempatan berpartisipasi sebesar $73 \%$ dan masuk kategori baik.

7. Kemampuan mahasiswa PPL dalam indikator keterampilan mengelola kelas sudah baik. Ini dapat terlihat dari hasil prosentase sub-sub indikator keterampilan mengelola kelas berkategori baik, dan 
sub indikator yang paling mempengaruhi kemampuan mahasiswa PPL dalam keterampilan mengelola kelas adalah memusatkan perhatian kelompok yang memiliki hasil prosentase paling tinggi dibandingkan dengan sub indikator lainnya. Prosentase memusatkan perhatian kelompok sebesar $82 \%$ dan masuk kategori sangat baik.

8. Kemampuan mahasiswa PPL dalam indikator keterampilan dasar mengajar kelompok kecil dan perseorangan sudah baik. Ini dapat terlihat dari hasil prosentase sub-sub indikator keterampilan dasar mengajar kelompok kecil dan perseorangan berkategori baik, dan sub indikator yang paling mempengaruhi kemampuan mahasiswa PPL dalam keterampilan dasar mengajar kelompok kecil dan perseorangan adalah pendekatan secara pribadi yang memiliki hasil prosentase paling tinggi dibandingkan dengan sub indikator lainnya. Prosentase pendekatan secara pribadi sebesar $80 \%$ dan masuk kategori sangat baik.

Jadi, pelaksanaan kegiatan PPL di sembilan SMK Negeri yang ditunjuk UNJ sudah terlaksana dengan baik. Ini dapat terlihat dari hasil prosentase indikator-indikator keterampilan dasar mengajar berkategori baik. Ini artinya kegiatan Program Pengalaman Lapangan Jurusan Teknik Sipil sudah berjalan dengan baik. Hasil belajar siswa SMK pada bidang keahlian teknik bangunan gedung yang diajarkan oleh mahasiswa PPL, dapat dilihat dari nilai UTS yang berada dalam kategori sangat baik dengan nilai rerata 80,2 .

Keterampilan dasar mengajar mahasiswa PPL FT UNJ mempunyai hubungan yang cukup dengan hasil belajar siswa pada bidang keahlian teknik bangunan gedung, yaitu dapat dilihat dari hasil analisis korelasi dengan koefisien korelasi $\left(r_{x y}\right)$ sebesar 0,489 .

\section{Saran}

Berdasarkan kesimpulan yang telah dipaparkan di atas, berikut ini dikemukakan beberapa saran terkait dengan simpulan tersebut, yaitu :

1. UNJ sebagai LPTK diharapkan dapat terus menciptakan lulusan atau calon guru yang profesional, serta mengarahkan dan meningkatkan minat lulusannya untuk lebih memilih menjadi guru dari pada profesi lain.

2. Program Pengalaman Lapangan (PPL) sebagai suatu ajang peningkatan kemampuan guru, sangat diharapkan memberikan pengalaman lapangan bagi calon guru dan memberikan kesempatan sebesar-besarnya untuk dapat mengaplikasikan ilmu yang telah diperoleh serta untuk mengembangkan ilmu yang dimiliki oleh calon guru.

3. Mahasiswa PPL hendaknya lebih meningkatkan keterampilan dasar mengajarnya terutama dalam keterampilan memberikan penguatan baik penguatan verbal maupun non verbal yang bertujuan untuk meningkatkan perhatian siswa terhadap pembelajaran dan merangsang serta meningkatkan motivasi belajar sehingga dapat meningkatkan prestasi belajar siswa misalnya dengan memberikan

Perbedaan Pembelajaran Menggunakan Aplikasi Multimedia Presentasi dengan Pembelajaran Media Program Pengolah Kata terhadap Hasil Belajar Mata Pelajaran Teori Kejuruan Teknik Furnitur (Studi pada Mata Pelajaran Kejuruan Furnitur Kelas XI SMKN 52 Jakarta) 
kata-kata pujian atau melakukan gerakan seperti mengacungkan jempol kepada siswa yang menjawab pertanyaan dengan tepat.

4. Siswa harus meningkatkan prestasi belajarnya dengan tekun belajar dan berlatih, dan mengembangkan pengetahuan dengan mencari bahan ajar dan sumber belajar lain dengan tidak hanya mengandalkan guru sebagai sumber informasi tunggal.

5. Bagi kepentingan studi dan penelitian lebih lanjut, bahwa penelitian ini belum mencapai tujuan yang optimal sebagaimana yang diharapkan, karena masih memiliki kekurangan/kelemahan. Oleh karena itu disarankan agar penelitian ini menjadi bahan pembanding bagi penelitian yang sama.

\section{DAFTAR PUSTAKA}

A.M., Sardiman. 2011. Interaksi dan Motivasi Belajar Mengajar. Jakarta: PT Raja Grafindo Persada.

Arikunto S. 2001. Dasar-dasar Evaluasi Pendidikan. Jakarta : Bumi Aksara.

Arikunto, Suharsimi. 2002. Prosedur Penelitian Suatu Pendekatan dan Praktek. Jakarta: Rineka Cipta.

Usman, Basyiruddin. 2002. Media Pembelajaran. Jakarta: Ciputat Pers

Buku Pedoman Skripsi/Komprehensif/Karya Inovatif (S1). 2009. Jakarta: FT UNJ Press.

Buku Pedoman Program Pengalaman Lapangan (PPL). 2010. Jakarta: FT UNJ Press.

Dimyati dan Moedjiono. 2002. Belajar dan Pembelajaran. Jakarta: PT. Rineka Cipta

Hamalik, Oemar. 2006. Proses Belajar Mengajar. Bandung: Bumi Aksara.

Riduwan. 2004. Belajar Mudah Penelitian Untuk Guru-Karyawan Dan Peneliti Pemula. Bandung: Alfabeta.

Tu'u, Tulus. 2004. Peran Disiplin pada perilaku dan prestasi siswa. Jakarta: PT. Gramedia Widiasarana Indonesia.

Sardiman A.M,. 2005. Interaksi \& Motivasi Belajar Mengajar. Jakarta: Raja Grafindo Persada.

Singarimbun, Masri dan Sofian Effendi. 1998. Metode Penelitian Survai. Jakarta: PT Pustaka LP3ES Indonesia.

Slameto. 2010. Belajar dan Faktor-faktor yang Mempengaruhinya. Jakarta: Rineka Cipta.

Sudijono, Anas. 2000. Pengantar Statistik Pendidikan. Jakarta : PT. Raja Grafindo Persada.

Sudjana, D. 2000. Strategi Pembelajaran Dalam Pendidikan Luar Sekolah. Bandung : Nusantara Press.

Sugiyono. 2007. Metode Penelitian Pendidikan. Bandung: Alfabeta

Sukirman, Dadang dan Nana Jumhana, 2011 Perencanan Pembelajaran. Bandung: UPI Press

Sukmadinata. 2008. Metode Penelitian Pendidikan. Bandung: Rosdakarya.

Syah, Muhibbin. 2002. Psikologi Pendidikan dengan Pendekatan Baru. Bandung: Rosdakarya 
Uno, Hamzah B. 2010. Orientasi Baru dalam Psikologi Pendidikan. Jakarta: Bumi Aksara.

Usman, Uzer. 2009. Menjadi Guru Profesional. Bandung: PT Remaja Rosdakarya.

Perbedaan Pembelajaran Menggunakan Aplikasi Multimedia Presentasi dengan Pembelajaran Media Program Pengolah Kata terhadap Hasil Belajar Mata Pelajaran Teori Kejuruan Teknik Furnitur

(Studi pada Mata Pelajaran Kejuruan Furnitur Kelas XI SMKN 52 Jakarta)

Hadi Mukhlish, $T$ uti Iriani, R. Eka Murtinugraha 